\title{
Article \\ Selectively Producing Acetic Acid via Boric Acid-Catalyzed Fast Pyrolysis of Woody Biomass
}

\author{
Xueli Hou, Zhen Li and Zhijun Zhang * \\ Key Laboratory of Bio-Based Material Science and Technology of Ministry of Education, \\ Material Science and Engineering College, Northeast Forestry University, Harbin 150040, China; \\ hxl-1996@nefu.edu.cn (X.H.); lzmx666@nefu.edu.cn (Z.L.) \\ * Correspondence: zjzhang2015@nefu.edu.cn; Tel.: +86-156-6382-6738
}

Citation: Hou, X.; Li, Z.; Zhang, Z. Selectively Producing Acetic Acid via Boric Acid-Catalyzed Fast Pyrolysis of Woody Biomass. Catalysts 2021, 11, 494. https://doi.org/10.3390/ catal11040494

Academic Editors: Consuelo Alvarez-Galvan and Jose M. Campos-Martin

Received: 3 March 2021

Accepted: 9 April 2021

Published: 13 April 2021

Publisher's Note: MDPI stays neutral with regard to jurisdictional claims in published maps and institutional affiliations.

Copyright: (c) 2021 by the authors. Licensee MDPI, Basel, Switzerland. This article is an open access article distributed under the terms and conditions of the Creative Commons Attribution (CC BY) license (https:/ / creativecommons.org/licenses/by/ $4.0 /)$.
Abstract: Boric acid is recently proved to be a good substitute for conventional acidic catalytic materials. However, few studies used boric acid as a catalyst in biomass pyrolysis. This study focused on the catalytic effects of boric acid (BA) on pyrolysis behaviors of woody biomass. The birch wood flour (WF) was used as feedstock and treated by impregnation of boric acid solution. Both untreated and boric acid-treated samples (BW) were characterized by FTIR and SEM. Thermogravimetry (TG) and pyrolysis coupled with gas chromatography and mass spectrometry (Py-GC/MS) techniques were used for studying mass loss, composition, and distribution of evolved volatiles formed from pyrolysis process. Additionally, a small fixed-bed pyrolyzer with an amplificated loading amount was used to prepare liquid products, and further, GC/MS were used to analyze the composition of these liquid products. Different pyrolysis temperatures and boric acid/wood flour mass ratios were also studied. The main results are as follows. Boric acid infiltrated into both cell cavity and cell wall through impregnation treatment. FTIR analysis showed that boric acid reacted with wood flour to form B-O-C bond during the treatment. After the treatment of boric acid, the initial degradation temperatures and residual carbon contents were increased, while the maximum weight loss rates were decreased. Boric acid significantly altered the composition and distribution of volatile pyrolysis products of wood flour. It significantly increased the contents of small molecule compounds such as acetic acid and furfural but, decreased the contents of phenol derivatives with high molecular weights. And these changes became more pronounced as the temperature increased. When mass ratio of boric acid (BA) to wood flour (WF) was 2, the acetic acid accounted for $91.28 \%$ of the total product in the pyrolysis liquid, which was 14 times higher than that of untreated wood flour. Boric acid effectively catalyzed fast pyrolysis of woody biomass to selectively produce acetic acid

Keywords: woody biomass; fast pyrolysis; boric acid; acetic acid; pyrolysis characteristics

\section{Introduction}

Environmental pollution and energy shortage have become the main contradictions restricting the sustainable development of economy and society. Biomass has attracted people's attention for its renewability, availability, carbon neutrality, less dependency on fossil fuels, and other advantages [1-4]. Woody biomass derived from trees is a vital biomass resource since new forests can be regenerated through afforestation and appropriate maintenance [5]. The construction scrap wood is almost completely utilized in construction materials. However, only a small amount of the wood wastes generated in wood products and paper industries, such as wood chips, lumber, and furniture mill sawdust were recycled to produce heat and electricity in power plants [6-8]. It is very important to make full use of the existing wood resources, especially waste wood. In fact, besides the direct combustion (burning) to produce heat, as the only renewable carbon resource, woody biomass also can be recycled to produce materials such as scrimber, fiberboards, and composites to produce solid, gaseous, and liquid fuels and to produce high value-added chemicals [9-12]. Thermochemical conversion processes, especially fast pyrolysis technology has been considered 
as a typical and promising method for effectively converting biomass into high-value chemicals and bio-fuels in a short time by rapid heating $[2,13,14]$. However, owing to the complexity of biomass structure and various pyrolysis reaction pathways, the bio-crude produced from biomass pyrolysis contains a large number of oxygenated compounds such as acids, aldehydes, ketones, dehydrated sugars and phenols, which make it difficult to be directly used as liquid fuel or chemicals $[15,16]$. Frequently, in order to promote the yield of desired chemicals, appropriate catalysts were used to adjust the composition and distribution of pyrolysis products via selectively enhancing some specific reactions that occur in the pyrolysis processes [9,17-20]. Inorganic salts, metal oxides, and zeolites have been used as catalysts for this purpose [4,21-24]. HZSM-5 improves the acid and furan yields at low temperature by promoting dehydration and retro-aldol fragmentation during the in-bed catalytic pyrolysis of hemicellulose monosaccharide $[19,25,26]$. Zinc chloride promotes the formation of furfural by catalyzing the dehydration, depolymerization, and ring opening reactions of biomass [27].

Boric acid is recently proved to be a good substitute for conventional acidic catalytic materials [28-35]. It successfully catalyzed various types of reactions such as fructose dehydration, salicylic acid esterification, and condensation between aldehyde and ketone $[28,29,31,32,35]$. Additionally, it has been proved that boric acid can react with methanol and polyhydroxy compounds such as D-Mannitol, D-glucose, and D-fructose to form boric acid esters $[32,33]$. However, boric acid is rarely used as catalyst for biomass pyrolysis.

In fact, for several decades, boric acid, owing to its easy commercial availability and environmentally friendly characteristics, has been primarily used as a bactericide and flame retardant for wood biomass $[5,36,37]$. Boric acid could reduce the maximum degradation temperature and increase the residual char amount of wood biomass [38,39]. It is generally assumed that boric acid mainly plays a role in the inhibition of both heat and mass transfer during the biomass pyrolysis processes [33]. Moreover, some researchers stated that boric acid can act as a catalyst for some specific reactions, such as dehydration, isomerization, etc. $[28,30,31,34,35]$. Wang et al. presented that boric acid not only catalyzes dehydration and deoxidation reactions of wood at $100-300{ }^{\circ} \mathrm{C}$ but also catalyzes isomerization of newly formed intermediates to finally form aromatic structure and char [33]. Zhang et al. discovered that complexation and esterification reactions occur between wood fiber and boric acid, which promoted the char formation [34]. However, there are few reports about the preparation of chemicals from biomass catalyzing over boric acid.

Thus, this study aimed to catalytically convert woody biomass into chemicals such as acetic acid and furfural via fast pyrolysis over the boric acid. Acetic acid is often used as a solvent and raw material in agriculture, medicine, and the dyestuff industry, while furfural is a fundamental raw material of fine chemicals and widely applied in synthetic rubber, plastics, medicine, pesticides, and other industries [40,41]. In this study, birch wood flour (WF) was used as the feedstock and treated by impregnation with boric acid solution. The mass loss, composition, and distribution of evolved volatiles formed from pyrolysis process were studied by using thermogravimetry (TG) and Py-GC/MS techniques. Additionally, the pyrolysis liquid products were prepared by a small fixed-bed pyrolyzer and further analyzed by a GC/MS technique. Different pyrolysis temperatures and boric acid/wood flour mass ratios were also studied.

\section{Results and Discussion}

\subsection{Feedstock Characterization}

The feedstock used in this study was birch wood powder. The elemental analysis and proximate analysis as well as the chemical composition of birch feedstock are presented in Table 1. 
Table 1. The proximate, elemental and compositional analyses of the birch feedstock.

\begin{tabular}{ccccccccc}
\hline & \multicolumn{9}{c}{ Elemental (wt. \%) } & \multicolumn{3}{c}{ Proximate (wt. \%) } \\
\cline { 2 - 8 } Birch & $\mathbf{C}$ & $\mathbf{H}$ & $\mathbf{O}$ & $\mathbf{N}$ & $\mathbf{S}$ & Volatile matter & Ash & Fixed carbon \\
& 44.52 & 6.06 & 45.71 & 3.16 & 0.55 & 79.43 & 4.15 & 16.42 \\
\cline { 2 - 8 } & \multicolumn{9}{c}{ Chemical composition (wt. \%) } \\
\cline { 2 - 8 } & Holocellulose & \multicolumn{3}{c}{ Lignin } & $\alpha$-cellulose & Extract \\
75.76 & & 23.02 & 48.87 & 2.23 \\
\hline
\end{tabular}

\subsection{FTIR Characteristics}

Figure 1a displays the FTIR spectra of the untreated wood flour (WF), boric acid (BA), and BA/WF mixtures with different mass ratios (0.1:1, 0.5:1, 1:1, 2:1). Compared with those untreated samples and pure boric acid, new infrared absorption peaks appeared at 3200 , $1375,1340,1195,945$, and $815 \mathrm{~cm}^{-1}$ in the infrared spectrum of BA-treated wood flour. This not only proved the successfully loading of BA on wood flour, but also implied some reactions occurred after BA treatment. This is in accord with other research results showing that boric acid could react with wood fiber to form boron complex [34].

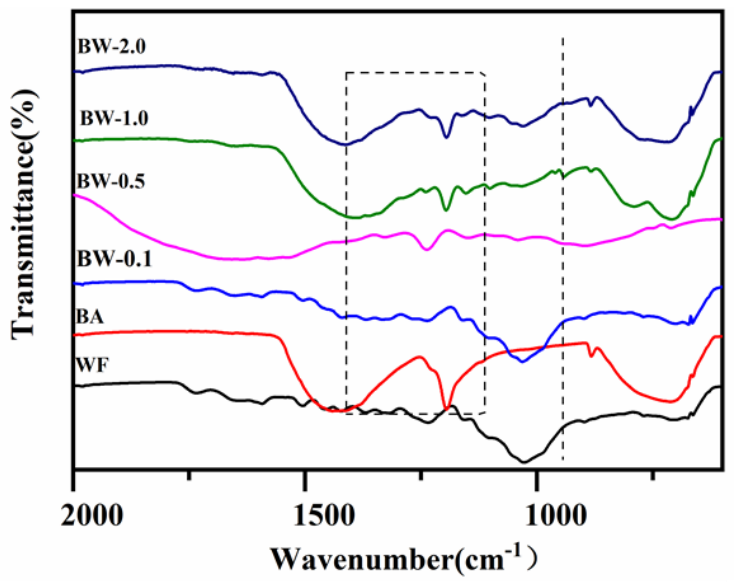

(a)

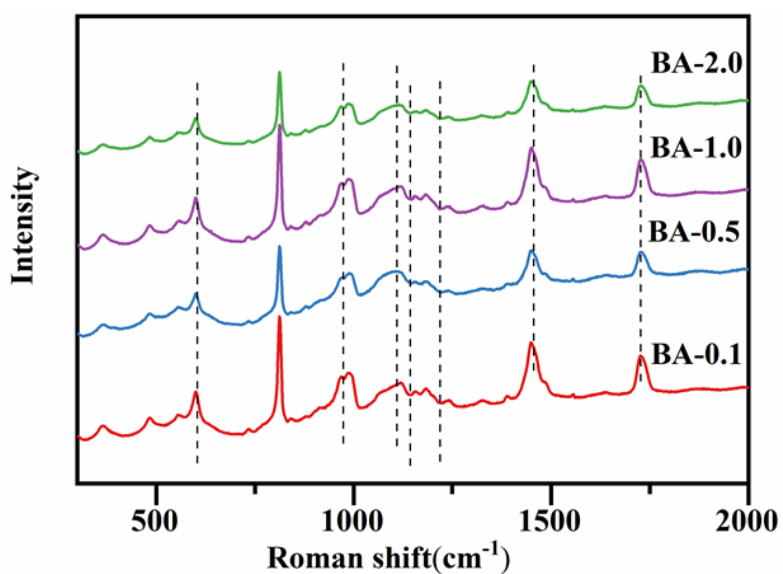

(b)

Figure 1. (a) FTIR spectra of wood flour (WF), boric acid (BA) and BA/WF mixtures with different ratios (0.1:1, 0.5:1, 1:1, 2:1 $w t / w t)$; (b) Raman spectra of boric acid aqueous solution (with different concentrations).

In Raman spectra (Figure 1b), strong Raman scattering characteristic peaks can be observed at $601,811,988,1118$, and $1449 \mathrm{~cm}^{-1}$. The IR peak at $3200 \mathrm{~cm}^{-1}$ was ascribed to the stretching vibration-OH in boric acid. The IR absorption peak at $1375 \mathrm{~cm}^{-1}$ was attributed to the unsymmetrical stretching vibration of the $\mathrm{B}-\mathrm{O}$ bond in $\mathrm{B}(\mathrm{OH})_{3}$. The absorption peak at $1340 \mathrm{~cm}^{-1}$ was attributed to the bridge stretching vibration of the B-O-C bond [42], corresponding to the scattering characteristic peak at $1338 \mathrm{~cm}^{-1}$ in the Raman spectrum. The flexural vibration of the B-O bond observed at $1195 \mathrm{~cm}^{-1}$ was in line with the Raman scattering peak at $1183 \mathrm{~cm}^{-1}[42,43]$. The weak infrared absorption peak at $945 \mathrm{~cm}^{-1}$ indicated the existence of the $-\mathrm{BO}_{4}$ bond. The peak at $1118 \mathrm{~cm}^{-1}$ in the Raman spectrum was related to the $\mathrm{B}-\mathrm{O}$ symmetric stretching vibration. Polyborate anions formed in the concentrated boric acid solution. The absorption peak at $1270 \mathrm{~cm}^{-1}$ belonged to the stretching vibration of the B-O bond in cyclic boride. It demonstrated that boric acid polymerize in aqueous solution $[43,44]$. The characteristic scattering vibrations of $\left[\mathrm{B}_{6} \mathrm{O}_{7}(\mathrm{OH})_{6}\right]^{2-}$ can be observed at $967 \mathrm{~cm}^{-1}$. The symmetrical pulse vibration of $\left[\mathrm{B}_{4} \mathrm{O}_{5}(\mathrm{OH})_{4}\right]^{2-}$ appeared at $554 \mathrm{~cm}^{-1}$. The Raman scattering at $732 \mathrm{~cm}^{-1}$ was identified as the symmetric pulse vibration of $\left[\mathrm{B}(\mathrm{OH})_{4}\right]^{-}$. The scattering characteristic vibration of $\left[\mathrm{B}_{3} \mathrm{O}_{3}(\mathrm{OH})_{4}\right]^{-}$appeared at $840 \mathrm{~cm}^{-1}$, and the symmetric pulse vibration of $\left[\mathrm{B}_{3} \mathrm{O}_{3}(\mathrm{OH})_{4}\right]^{-}$ appeared at $988 \mathrm{~cm}^{-1}$. These results suggest that self-polymerization reactions of boric 
acid occur, forming boric acid trimer, tetramer, and hexamer in the processes of boric acid pretreatment and pyrolysis initial stage where approximated conditions existed.

\subsection{Scanning Electron Microscopy}

Figure 2 shows the SEM micrographs of different samples (the corresponding original images are shown in Figure S2 in the Supplementary Materials). Compared with untreated wood flour, the surface morphology of wood flour treated by boric acid changed significantly. The surface of untreated wood fiber was clean (Figure 2a), and it became uneven after treatment. In Figure $2 b, c$, the pits on the cell wall were blocked by boric acid, and in Figure $2 \mathrm{~d}$, boric acid filler was obviously seen in ray tracheid. Boric acid exists as solid sediments deposited in/on the cell cavity and cell wall of wood. This is in accord with the point that inorganic modifier with a small molecular weight could infiltrate into both cell cavity and cell wall through impregnation treatment [5]. With the increase of BA/WF ratio, the surface depositions of boric acid particles on wood fiber were increased. A glassy heterogeneous film of BA formed on the surface of wood fiber (Figure 2d,e). Figure 3 shows the electron energy spectrum of BW-1.0. It indicates the presence and uniform distribution of boron element.

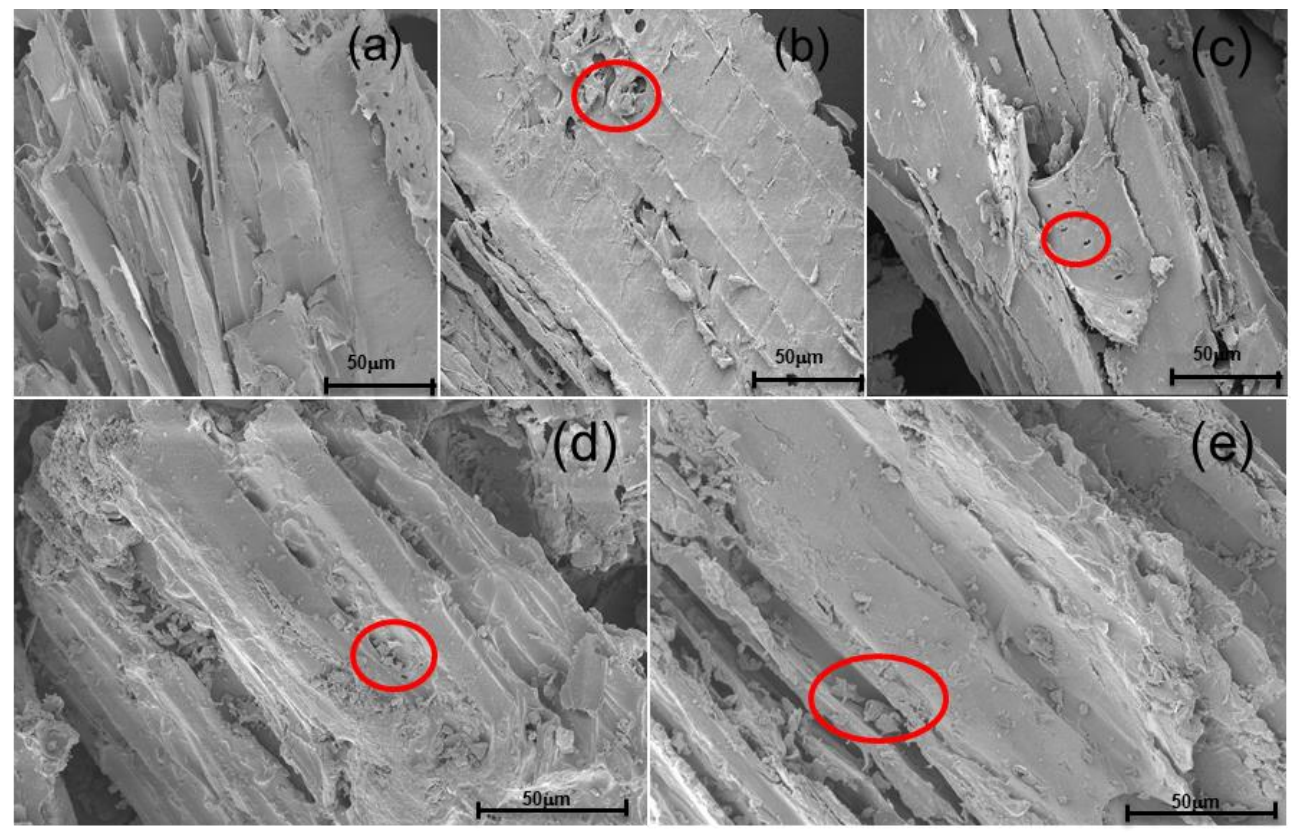

Figure 2. The SEM images of (a) wood flour $(\mathrm{WF})$ and BA/WF mixtures with different mass ratios $((\mathbf{b}) \mathrm{BA} / \mathrm{WF}=0.1$; (c) $\mathrm{BA} / \mathrm{WF}=0.5 ;(\mathbf{d})$ and $(\mathbf{e}) \mathrm{BA} / \mathrm{WF}=2.0 ; \times 1000)$.

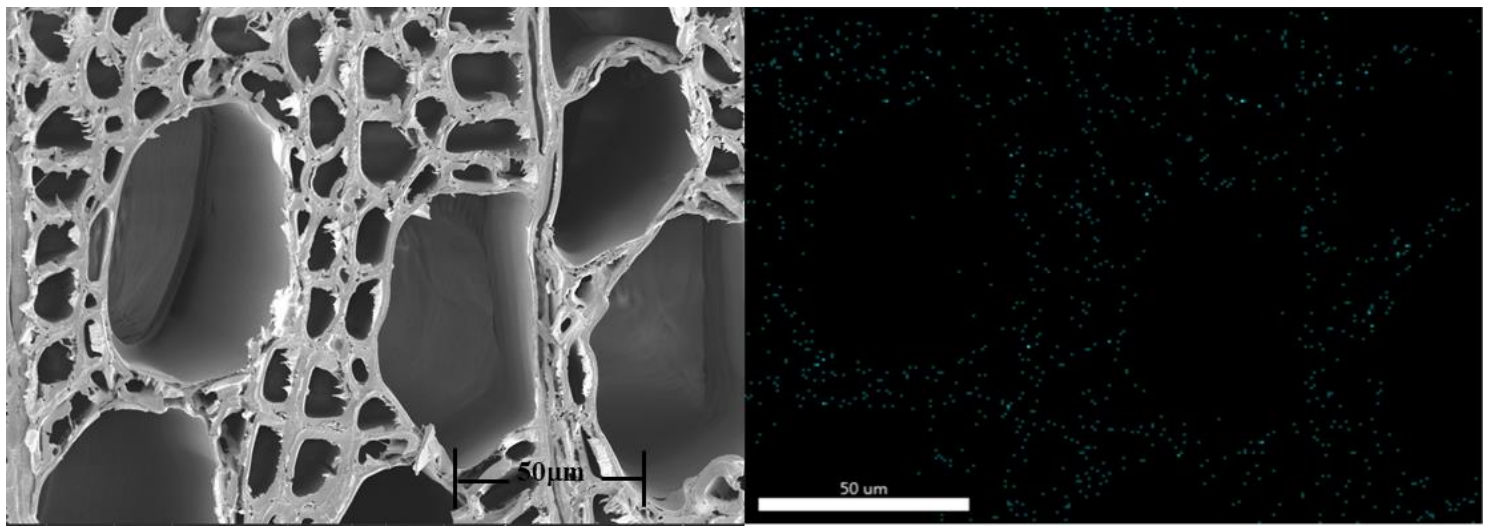

Figure 3. The SEM and EDX images of the BW-1.0 sample (mass ratio of BA/WF is 1$)(\times 1000)$. 


\subsection{Pyrolysis Characteristics of Samples}

Figure 4 shows the TG-DTG profiles of boric acid and boric acid-treated and untreated wood flour. Table 2 lists the pyrolysis characteristic parameters of all these samples. Boric acid initially decomposes into $\mathrm{H}_{2} \mathrm{O}(\mathrm{g})$ and metaboric acid $\left(\mathrm{HBO}_{2}\right)$ at around $160{ }^{\circ} \mathrm{C}$. Metaboric acid melts at about $236^{\circ} \mathrm{C}$ and dehydrates to form pyroboric acid when heated above $300{ }^{\circ} \mathrm{C}$. Further heating (about $330{ }^{\circ} \mathrm{C}$ ) leads to boron trioxide [45]. The whole pyrolysis processes of all the samples except BA can be divided into approximately three stages. The mass loss at the first stage $\left(50-200^{\circ} \mathrm{C}\right)$ was mainly related to removal of water, $\mathrm{CO}_{2}, \mathrm{CO}$, and other small molecule volatile compounds. The mass loss in the second stage $\left(200-400^{\circ} \mathrm{C}\right)$ was ascribed to the degradation of cellulose, hemicellulose, and lignin. Conversion of non-volatile and noncombustible parts of wood into tar or coke mainly occurred in the third stage $\left(400-700^{\circ} \mathrm{C}\right)$.

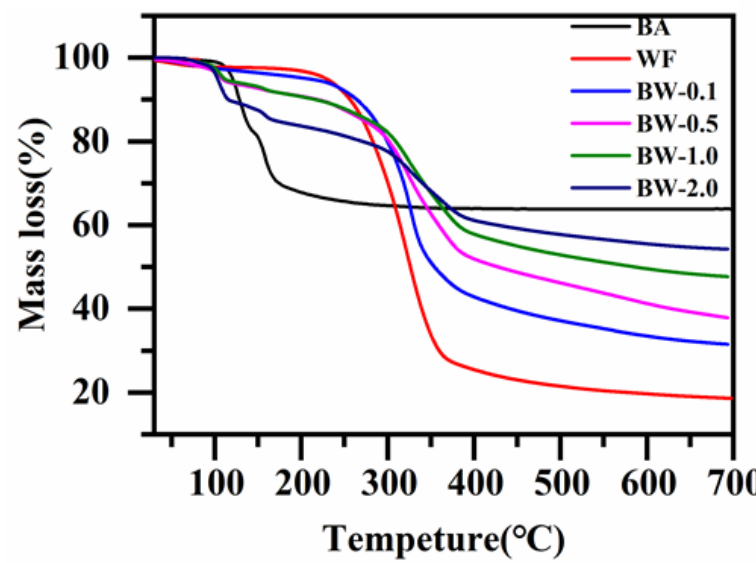

(a)

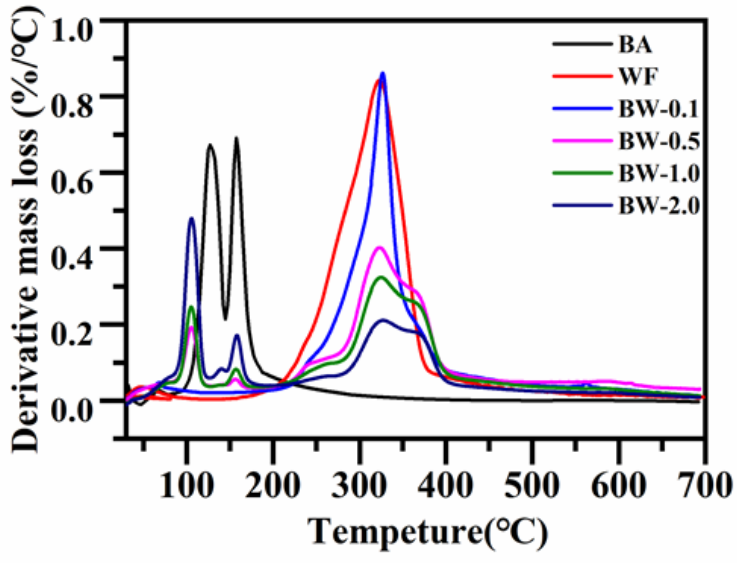

(b)

Figure 4. Thermogravimetry (TG) curves (a) and differential thermogravimetric (DTG) curves (b) from the thermal decomposition of wood flour (WF), boric acid (BA), and BA/WF mixtures with different ratios (0.1:1, 0.5:1, 1:1, 2:1 wt/wt).

Table 2. Pyrolysis parameters of all samples.

\begin{tabular}{ccccccc}
\hline & \multirow{2}{*}{$\mathbf{T}_{\mathbf{i}}$} & \multirow{2}{*}{$\mathbf{T}_{\mathbf{m a x}}$} & $\begin{array}{c}\text { Temperature } \\
\text { Range of Most } \\
\left({ }^{\circ} \mathbf{C}\right)\end{array}$ & $\left({ }^{\circ} \mathbf{C}\right)$ & & \multicolumn{3}{c}{ Residual Mass (\%) } \\
\cline { 5 - 7 } & & & Weight Loss & $\begin{array}{c}\text { Experimental } \\
\text { Value }\end{array}$ & $\begin{array}{c}\text { Adjust } \\
\text { Value }\end{array}$ & $\begin{array}{c}\text { Theoretical } \\
\text { Value }\end{array}$ \\
\hline WF & 268.3 & 319.1 & $268.3-356.4$ & 22.05 & - & - \\
BA & 114.9 & 123.1 & $114.9-128.4$ & 54.94 & - & - \\
BW-0.1 & 286.6 & 319.6 & $286.6-349.9$ & 27.29 & 21.80 & 25.33 \\
BW-0.5 & 287.2 & 320.9 & $287.2-365.9$ & 38.80 & 20.49 & 33.01 \\
BW-1.0 & 288.5 & 321.1 & $288.5-376.1$ & 50.51 & 23.04 & 38.50 \\
BW-2.0 & 292.5 & 324.6 & $292.5-378.1$ & 58.09 & 21.46 & 43.97 \\
\hline
\end{tabular}

$\mathrm{T}_{\mathrm{i}}$ (initial degradation temperature), $\mathrm{T}_{\max }$ (the temperature corresponding to the maximum mass loss rate), and residual mass (in \%) of BA impregnated WF measured at $700{ }^{\circ} \mathrm{C}$; adjusted value was obtained by proportionally subtracting the residue mass value of boric acid from the related experimental value; theoretical value was acquired by simple mathematical summation of respective residue masses of both wood and BA components.

Boric acid treatment affected the thermochemical properties of wood flour significantly. The initial degradation temperatures $\left(T_{i}\right)$ and the temperature corresponding to the maximum mass loss rate $\left(\mathrm{T}_{\max }\right)$ as well as the residual carbon contents were increased, while the maximum weight loss rate was decreased. Compared with the untreated sample, the $T_{i}$ values of the BA-treated samples (BW-0.1, BW-0.5, BW-1.0, and BW-2.0) increased by $6.82 \%, 7,04 \%, 7.53 \%$, and $9.02 \%$, respectively. It proved that boric acid remarkably improves the thermal stability of wood. The residual masses were increased by $23.76 \%$, $83.54 \%, 129.07 \%$, and $163.45 \%$, respectively. These were consistent with Wang's results [33]. However, it is worth mentioning that besides the coke (fix carbon) and ash that originated 
from the wood, boron trioxide that formed from BA dehydration was also included in the pyrolysis residue. An adjusted value for the real residue mass derived from wood was obtained by proportionally subtracting the residue mass value of boric acid from the related experimental value (Table 2). It is based on the hypotheses that, in the BA-treated wood samples, boric acid could dehydrate fully as it decomposes alone, generating a boron trioxide that exists in a form of glassy nonvolatile liquid substance in the temperature range from $450{ }^{\circ} \mathrm{C}$ (melting point) to $1860^{\circ} \mathrm{C}$ (boiling point). In this case, boric acid had little impact on the residue formation of wood. Nevertheless, when comparing the experimental value of residue with its related theoretical value acquired by simple mathematical summation of respective residue masses of both wood and BA components, the values of all the formers were higher than those of the latters. This implied that there exists a chemical interaction between wood and boric acid. Wood may inhibit dehydration of BA from releasing water. In another words, some incompletely dehydrated products, such as tetraborate and boron triborate remained in the residue. BA may catalytically change the pyrolysis path of wood, presenting varied thermal stabilities and pyrolysis products. This is in accord with the views that boric acid can react with alcohols to form borate esters, especially, with polyols containing cis-vicinal diols, such as glycerol and mannitol, to form a boron-containing chelate [32].

\subsection{Py-GC/MS Analysis of Samples}

Py-GC/MS was used to investigate the composition and distribution of evolved volatiles formed from the pyrolysis process. Figure 5 shows the total ion chromatograms of pure wood flour and boric acid/wood flour mixtures with different mass ratios (0.1:1, $0.5: 1,1: 1,2: 1)$ obtained by Py-GC/MS at $500{ }^{\circ} \mathrm{C}$ for $60 \mathrm{~s}$. The main pyrolysis volatile's compositions and distributions of these samples were shown in Figure 6. Apparently, BA treatment simplified the product composition of the wood flour samples. Eighty-three kinds of compounds were detected in the volatile pyrolysis products of untreated wood powder. However, 80, 44, 28, and 9 kinds of compounds were detected for BA-treated wood samples with varied BA/WF mass ratios from 0.1:1, 0.5:1, 1:1, and 2:1, respectively (Figure 5). This finding indicates that boric acid selectively inhibits the formation of some products and promotes the formation of other products. These pyrolysis products were mainly divided into 11 categories: aldehydes, furans, ketones, acids, esters, alcohols, phenols, saccharides, benzenes, hydrocarbons, and nitrogenous compounds. Compounds like furfural, 5-hydroxymethylfurfural, methylglyoxal, and hydroxyacetaldehyde were mainly formed from pyrolysis of glucose-based carbohydrates. This is because the glycosidic bond in cellulose is relatively weak, and it was easy to crack under acidic or high temperature conditions, largely generating furans and levoglucosan $[4,46,47]$. Additionally, furans, ketones, acetic acid, and anhydrosugars were derived from hemicellulose pyrolysis $[18,48,49]$. Lignin is composed of phenylpropane units. The main pyrolysis products of lignin are phenol derivatives, acetic acid, methanol, and other small molecular compounds [50].

With the increase of the BA/WF ratio, the contents of ketones and phenols were decreased, while the contents of acids, furans and lipids were increased significantly. When the BA/WF mass ratio was 2.0, a small number of ketones and aldehydes were detected, while acids, furans, and esters became the main compounds in the pyrolysis products. Especially, acetic acid was the main compound, and its content reached about $39.66 \%$ (percentage of area). These results show that boric acid treatment varied the decomposition paths of cellulose and hemicellulose, while it inhibited the decomposition of lignin to form phenols.

\subsection{Small Fixed-Bed Pyrolysis Study of Samples}

The loading amount of sample required in the Py-GC/MS test is about $0.5 \mathrm{mg}$. It is difficult to calculate the mass change before and after pyrolysis. In order to figure out the mass balance, a serial of bench-scale pyrolysis experiments were carried out on a small fixed-bed pyrolysis reactor, of which the sample amount was about $0.2 \mathrm{~g}$. Table 3 lists 
the mass balance (yields of volatiles and non-volatile residues) obtained from pyrolysis of pure wood powder and BA-treated wood powders with different mass ratios. BAtreatment lowered the yields of volatile but improved the yields of solid products to some extent. Additionally, with the increase of boric acid usage, this trend became even more pronounced. As described in Section 2.3, the increasing residue yields were mainly attributed to the mixing of the increasing pyrolysis residues of boric acid.

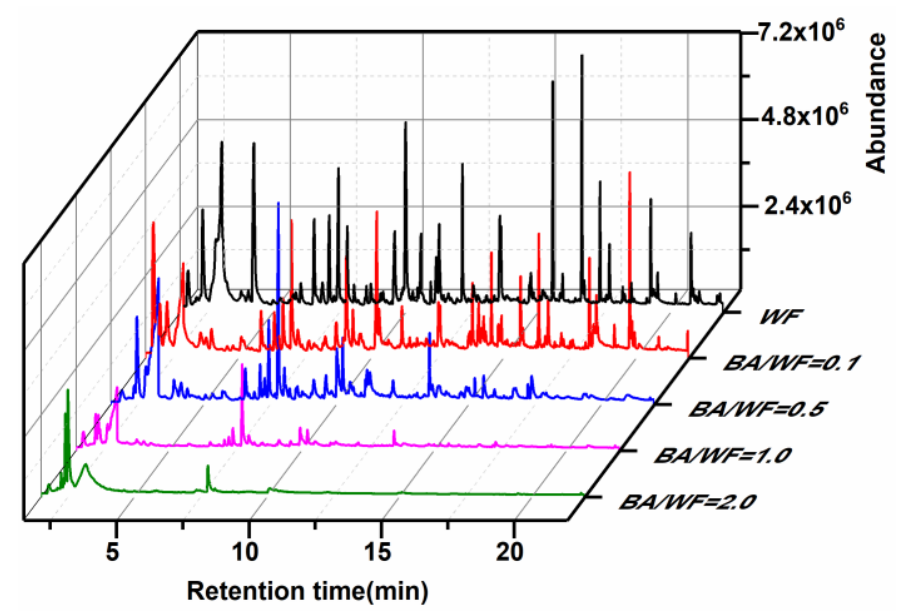

Figure 5. Total ion chromatograms of wood flour (WF)and boric acid/wood flour mixtures (BW) with different mass ratios (0.1:1, 0.5:1, 1:1, 2:1) obtained by Py-GC/MS at $500{ }^{\circ} \mathrm{C}$ for $60 \mathrm{~s}$.

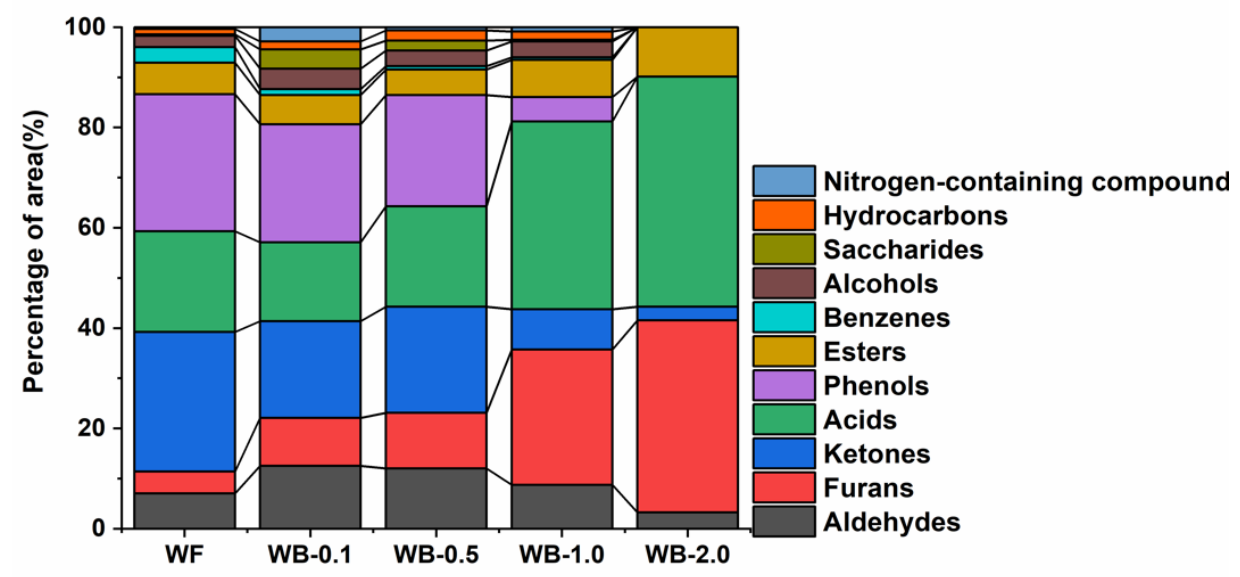

Figure 6. The main classification of pyrolysis volatiles of wood flour (WF) and boric acid / wood flour mixtures (BW) with different mass ratios $(0.1: 1,0.5: 1,1: 1,2: 1)$ obtained by Py-GC/MS at $500{ }^{\circ} \mathrm{C}$ for $60 \mathrm{~s}$.

Table 3. Volatile and solid product yield of all samples a .

\begin{tabular}{cccccc}
\hline & WF & BW-0.1 & BW-0.5 & BW-1.0 & BW-2.0 \\
\hline$w_{(v)} \%$ & $76.4 \pm 2.0$ & $66.9 \pm 1.8$ & $63.1 \pm 1.5$ & $61.9 \pm 1.7$ & $56.3 \pm 1.6$ \\
$w_{(s)} \%$ & $23.6 \pm 3.0$ & $33.1 \pm 2.0$ & $36.9 \pm 2.1$ & $38.2 \pm 2.4$ & $43.7 \pm 2.6$ \\
\hline a Experimental conditions: sample amount, 0.2 g; temperature, $500{ }^{\circ} \mathrm{C}$. &
\end{tabular}

Figure 7a compares the different total ion chromatograms of liquid products of untreated wood obtained by a small fixed-bed at varied pyrolysis temperatures of $400{ }^{\circ} \mathrm{C}$, $450{ }^{\circ} \mathrm{C}, 500{ }^{\circ} \mathrm{C}, 550{ }^{\circ} \mathrm{C}$, and $600{ }^{\circ} \mathrm{C}$. In sequence, a similar chromatogram comparison of BA-treated wood samples with a BA/WF mass ratio of $0.1,0.5,1.0$, and 2.0 are shown in Figure $7 \mathrm{~b}-\mathrm{e}$. The total number of pyrolysis products of untreated wood, especially those compounds with high relative molecular weight (refers to long retention times) increased with the increasing of pyrolysis temperature. Whereas the relative contents of each product 
obtained at all the temperatures were very low, it implies that complex reactions occurred in the pyrolysis processes (Figure 7a). Compared with untreated wood sample, obvious changes were observed on the compositions and distributions of pyrolysis liquid products of BA-treated wood samples (Figure 7a-e). Boric acid treatment significantly increased the contents of small molecule compounds, such as acetic acid and furfural, but decreased the contents of phenol derivatives with high molecular weights. For the sample with a BA/WF mass ratio of 0.1 , the product's composition and distribution changed obviously, the contents of boric acid and furfural were increased to some extent, but the composition of their pyrolysis products was still very complex. With the further increase of the boric acid dosage, especially when the mass ratio of boric acid/wood flour was over 0.1 , the total types of pyrolysis products were reduced. Meanwhile, the content of single compound was increased obviously. Remarkably, acetic acid and furfural almost became the main compounds when the mass ratio of BA/WF was 2.0. It implies that boric acid changes the distributions and relative contents of pyrolysis products by effectively inhibiting the formation of phenol derivatives and promoting the formation of acetic acid, furfural, and other small molecular compounds. For all the BA-treated samples, the temperatures studied in this study (from 400 to $600{ }^{\circ} \mathrm{C}$ ) had little effect on the distributions and compositions of the main products. In order to acquire a high liquid product's yield and low energy consumption, a modest temperature $\left(500^{\circ} \mathrm{C}\right)$ was fitted and selected for further study.

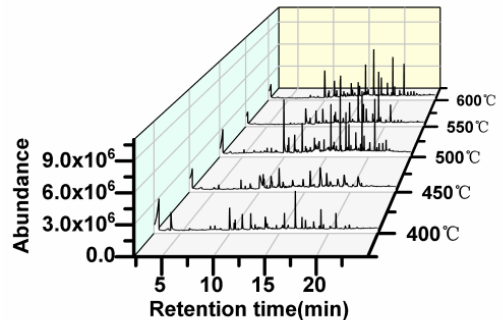

(a)

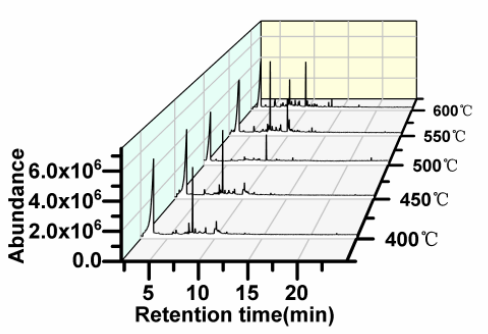

(d)

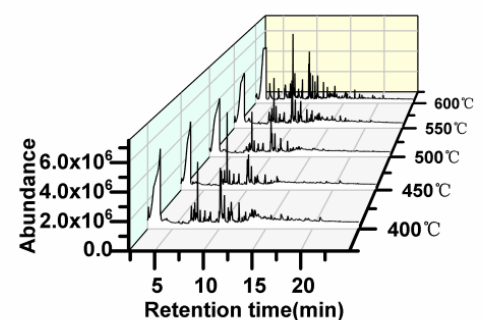

(b)

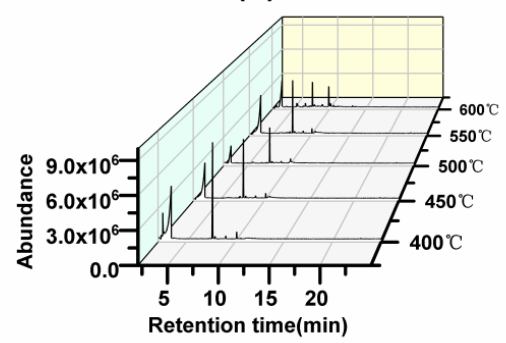

(e)

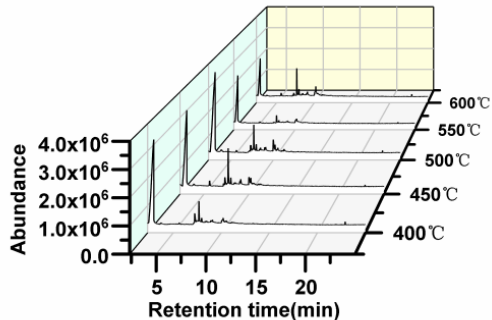

(c)

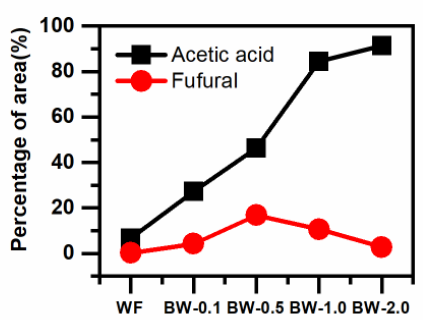

(f)

Figure 7. Gas chromatography and mass spectrometry (GC-MS) total ion chromatograms of liquid products from pyrolysis of (a) wood flour; (b) BA/WF $=0.1$; (c) BA/WF $=0.5$; (d) BA/WF $=1.0$; (e) BA/WF $=2.0$ at 400, 450, 500, 550, and 600 ${ }^{\circ} \mathrm{C}$; (f) comparison of the contents of both boric acid and furfural produced by pyrolysis of untreated wood and BA-treated wood samples with varied $\mathrm{BA} / \mathrm{WF}$ ratios at $500{ }^{\circ} \mathrm{C}$.

Table 4 shows the typical pyrolysis product compositions and distributions of untreated sample and BA-treated samples with varied BA/WF ratios at $500^{\circ} \mathrm{C}$. The comparison of the contents of both boric acid and furfural, the main compounds among these products are shown in Figure 7f. Apparently, boric acid treatment significantly improved the content of acetic acid in pyrolysis products of wood sample. With the increasing of $\mathrm{BA} / \mathrm{WF}$ ratio, the content of acetic acid increased gradually. When BA/WF ratio was 2.0, acetic acid content reached the maximum, accounting for $91.28 \%$ of the total content of all the detected products. This value was about 14 times higher than that of untreated wood sample. Conversely, the contents of phenol and its derivatives were decreased after boric acid treatment. The content of furfural in the pyrolysis liquid products of untreated wood sample was only $0.18 \%$. After boric acid treatment, its content first rose with the increase 
of BA/WF value and reached the maximum, accounting for $16.79 \%$ of the liquid pyrolysis products before it descended gradually when BA/WF ratio was over 0.5 .

Table 4. Peak area \% of the typical pyrolysis products of wood flour (WF) and boric acid / wood flour mixtures (BW) with different mass ratios $(0.1: 1,0.5: 1,1: 1,2: 1)$ obtained by a small fixed-bed pyrolysis reactor at $500{ }^{\circ} \mathrm{C}$.

\begin{tabular}{|c|c|c|c|c|c|c|}
\hline \multirow{2}{*}{$\begin{array}{l}\text { Retention } \\
\text { Time (min) }\end{array}$} & \multirow{2}{*}{ Compounds } & \multicolumn{5}{|c|}{ Peak Area (\%) } \\
\hline & & WF & BW-0.1 & BW-0.5 & BW-1.0 & BW-2.0 \\
\hline 2.25 & 1,2-Ethanediol & - & - & 11.47 & - & - \\
\hline 2.97 & Acetic acid & 6.56 & 27.19 & 46.24 & 84.48 & 91.28 \\
\hline 3.55 & Propanoic acid & 1.06 & 1.29 & 1.54 & 1.41 & - \\
\hline 4.70 & 4-Hydroxy-3-methyl-2-butanone & - & - & 2.39 & - & - \\
\hline 6.44 & Methyl acetic acid ester & - & - & 2.10 & - & - \\
\hline 7.01 & 1-Hydroxy-2-propanone & 1.48 & 0.96 & 0.57 & - & - \\
\hline 7.17 & 3-Furaldehyde & - & - & 0.74 & - & - \\
\hline 7.72 & Furfural & 0.18 & 4.19 & 16.79 & 10.57 & 2.81 \\
\hline 7.99 & 2-Cyclopenten-1-one & 1.43 & 1.48 & 1.75 & & 0.64 \\
\hline 8.38 & 5-Methyl-2(3H)-furanone, & - & 0.36 & 0.32 & - & - \\
\hline 8.46 & 1-(Acetyloxy)-2-propanone, & 0.44 & 0.74 & 0.78 & - & - \\
\hline 9.00 & 2-Methyl-2-cyclopenten-1-one, & 0.74 & 0.59 & 0.32 & - & - \\
\hline 9.09 & 1-(2-Furanyl)-ethanone, & 0.34 & 1.56 & 2.16 & - & - \\
\hline 9.39 & 5,6-Dihydro-2H-pyran-2-one, & - & 0.52 & 0.33 & - & - \\
\hline 9.55 & 2-Cyclopentene-1,4-dione & - & - & 0.67 & - & - \\
\hline 9.98 & Phenol & 12.86 & 8.44 & 4.30 & 2.6 & 2.0 \\
\hline 10.20 & 5-Methyl-2-furancarboxaldehyde, & - & 3.55 & 4.12 & - & - \\
\hline 10.42 & Butyrolactone & 1.67 & 0.40 & - & - & - \\
\hline 10.47 & 3-Methyl-2-cyclopenten-1-one, & 1.14 & 2.0 & 0.25 & - & - \\
\hline 10.52 & 2(5H)-Furanone & 1.50 & 3.3 & 0.95 & - & - \\
\hline 11.17 & 2,5-Dihydro-3,5-dimethyl 2-furanone, & 0.33 & 0.23 & - & - & - \\
\hline 11.25 & 2-Hydroxy-3-methyl-2-cyclopenten-1-one & 4.44 & 1.33 & - & - & - \\
\hline 11.42 & 2,3-Dimethyl-2-cyclopenten-1-one & 1.73 & 0.57 & - & - & - \\
\hline 11.72 & 3-Methyl-phenol, & 1.22 & 1.15 & - & - & - \\
\hline 12.05 & Methyl benzoic acid ester & 0.23 & 0.31 & - & - & - \\
\hline 12.14 & 2-Methoxy-phenol, & 4.56 & 2.10 & 0.40 & 0.48 & - \\
\hline 12.24 & 3-(2-Furanyl)-2-propenal, & - & - & 0.27 & - & - \\
\hline 12.55 & 3-Ethyl-2-hydroxy-2-cyclopenten-1-one, & 0.79 & 1.06 & - & - & - \\
\hline 12.89 & 3-Methyl-cyclohexanone, & 0.72 & 0.45 & 0.81 & - & - \\
\hline 13.05 & 2,5-Dimethyl-phenol, & 0.47 & 0.45 & - & - & - \\
\hline 13.20 & 2,4-Dimethyl-phenol, & 0.36 & 0.39 & - & - & - \\
\hline 13.46 & Levoglucosenone & - & 2.67 & - & - & - \\
\hline 13.61 & 2-Methoxy-4-methyl-phenol, & 2.09 & 1.83 & - & - & - \\
\hline 13.85 & Ethoxy-cyclohexane, & - & 2.62 & - & - & - \\
\hline 14.44 & 2,3-Dimethoxytoluene & 0.15 & 0.06 & - & - & - \\
\hline 14.76 & 4-Ethyl-2-methoxy-phenol, & 2.48 & 0.36 & - & - & - \\
\hline 15.56 & 2-Methoxy-4-vinyl-phenol & 4.80 & 2.36 & - & - & - \\
\hline 15.87 & 2-Methoxy-4-propyl-phenol, & 0.76 & 0.37 & - & - & - \\
\hline 15.95 & Eugenol & 0.89 & 0.35 & - & - & - \\
\hline 16.66 & 2,6-Dimethoxy-phenol, & 9.85 & 1.99 & - & - & - \\
\hline 17.05 & 4-Ethoxy-benzeneacetic acid, & 0.27 & - & - & - & - \\
\hline 17.36 & 2-Methoxy-4-(1-propenyl)-phenol, & 4.23 & 3.81 & - & - & - \\
\hline 17.72 & 4-Hydroxy-3-methoxy-benzoic acid, & 2.75 & 0.21 & - & - & - \\
\hline 18.55 & 1,2,3-Trimethoxy-5-methyl-benzene, & 3.17 & - & - & - & - \\
\hline 19.13 & 2-(4-Guaiacyl)-ethanol & 0.68 & - & - & - & - \\
\hline 19.28 & (E)-Stilbene & 6.59 & 3.36 & - & - & - \\
\hline 20.22 & 2,6-Dimethoxy-4-(2-propenyl)-phenol, & 10.64 & 12.27 & - & - & - \\
\hline 21.26 & n-Hexadecanoic acid & 0.55 & 0.99 & - & - & - \\
\hline 21.74 & 1-(4-Hydroxy-3,5-dimethoxyphenyl)-ethanone & 0.82 & - & - & - & - \\
\hline 22.18 & 1-(2,4,6-Trihydroxyphenyl)-2-pentanone & 0.89 & - & - & - & - \\
\hline 22.92 & Dibutyl phthalate & 0.37 & 0.27 & - & - & - \\
\hline Total & & 96.23 & 98.13 & 99.27 & 99.54 & 96.73 \\
\hline
\end{tabular}


It is worth noting that BA pre-treatment of woody samples change the morphology and the nature of the samples (confirmed by the SEM analyses) to some extent. This indicates that BA pre-treatment leads to some chemical transformation, for instance, partial hydrolysis of a wood sample. In order to find out whether the catalytic effect in the pyrolysis process or the structural change in the pretreatment process leads to the change of the pyrolysis products, the sample treated with boric acid was pyrolyzed after removal of boric acid, and its pyrolytic products were compared with those of untreated sample and boric acid treated sample (Figure 8a). Figure 8 shows their product distributions (a) and acetic acid contents (b) obtained at $500{ }^{\circ} \mathrm{C}$. The results show that both of them had an effect on the composition of the pyrolysis products, and that the latter was more significant. The acetic acid content of the BA-treated sample was about 6 times that of the untreated sample, but after removing boric acid, the value was about 2 times that of the untreated sample. Apparently, boric acid treatment has a positive effect on the formation of acetic acid while inhibiting the production of phenols, which were mainly derived from lignin pyrolysis. Both catalytic effects in the pyrolysis process and structural change in the pretreatment process are responsible for this.

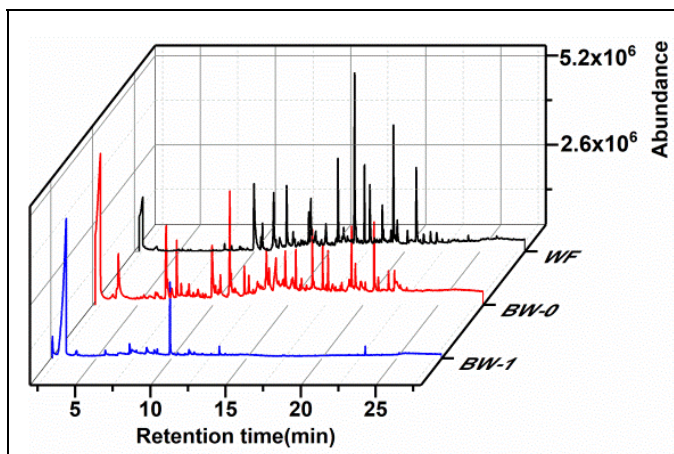

(a)

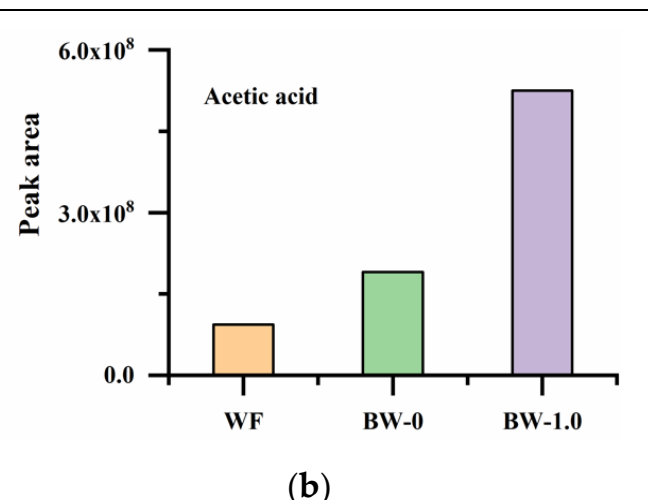

(b)

Figure 8. (a) Total ion chromatograms and (b) acetic acid contents of WF (wood flour), BW-1 (BA/WF mixture with a mass ratio 1) and BW-0 (BA-treated wood sample after removing boric acid) obtained by a small fixed-bed pyrolysis reactor at $500{ }^{\circ} \mathrm{C}$.

Acetic acid is mainly produced by pyrolysis of cellulose and hemicellulose [4,51]. In the pyrolysis process of hemicellulose, $\mathrm{O}$-acetyl group was released by both fracture of the $\mathrm{C}_{2}$-O bridged bond and ring-opening of the intermediates to produce acetic acid [52,53]. Secondary cracking of pyrolysis intermediates of cellulose may produce acetic acid too. Besides, acetic acid may form by further cracking of the acetyl group in the aliphatic chain of lignin components. Furfural and its derivative were the primary products of pyrolysis of cellulose and hemicellulose. Furfural compounds may form in two ways: (1) direct decomposition of oligosaccharides and (2) first, after oligosaccharides are converted to levoglucosan (LG) and levoglucosenone (LGO), and then LG/LGO is converted to furfural $[4,54]$. Additionally, the increase of furfural content may also be due to a decrease in the crystallinity of cellulose by boric acid impregnation (Figure S1). The cellulose with low crystallinity more easily formed furfural compounds [4]. Boric acid is a weak, monobasic Lewis acid of boron. However, some of its behavior toward some chemical reactions suggests it to be tribasic acid in the Brønsted sense as well. Therefore, although the detail mechanism of boric acid on wood pyrolysis is not completely clear, it is supposed that boric acid, like other acid catalysts, may fuction as an acid catalyst in promoting the ring-opening and cracking of cellulose, hemicellulose, and monosaccharides, resulting in an increase in the content of acetic acid, furfural, and other small molecule compounds. Besides, the converse variation trends for the contents of furfural and acetic acid at the high boric acid dosage imply that a competition exists between the formation of furfural and acetic acid. Moreover, furfural may convert into acetic acid in some form under these conditions. 


\section{Materials and Methods}

\subsection{Sample Preparation}

White birch wood was used as raw material for woody biomass in all experiments. It was obtained from Heilongjiang Province, China. The as-received birch wood was ground in a high-speed rotary cutting mill (DC 3-1, Benchen Technology Co, Ltd., Shenzhen, China) and screened to with a particle size of $180 \sim 250 \mu \mathrm{m}$ using a standard vibrating screen (BZS-200, CHINT, Jinan, China). The obtained sample (WF) was then dried at $105{ }^{\circ} \mathrm{C}$ for $48 \mathrm{~h}$. Boric acid (BA), with a AR grade, purchased from Tianjin Zhiyuan Chemical Reagent Co. Ltd. (Dongli District, Tianjin, China), was oven-dried at $103^{\circ} \mathrm{C}$ overnight before use.

The boric acid treated wood flour samples (BW) were prepared by impregnating the wood flour with boric acid aqueous solution. Samples with varying mass ratios of BA to WF $(0.1,0.5,1.0$, and 2.0 were marked as BW-0.1, BW-0.5, BW-1.0, and BW-2.0 separately) were obtained by adjusting the BA concentration. For example, first, to get BW-1.0 sample, $2.0 \mathrm{~g}$ of boric acid was added into a beaker that with about $100 \mathrm{~mL}$ of distilled water. Secondly, the beaker was heated in a water bath pot (preheated at $50{ }^{\circ} \mathrm{C}$ ) and stirred often until the BA completely dissolved in the water. Third, $2.0 \mathrm{~g}$ of wood powder was added into the BA aqueous solution, stirred fully with a glass rod for about $30 \mathrm{~min}$. Then the beaker was sealed with plastic wrap, kept in a dry place for $24 \mathrm{~h}$ to ensure that the wood flour was fully impregnated by boric acid solution. Finally, the sample was placed in an oven (set at $103 \pm 2{ }^{\circ} \mathrm{C}$ ) for $24-48 \mathrm{~h}$ until the sample's weight remained unchanged.

\subsection{Sample Characterization}

The proximate analysis including volatile matter (VM \%), moisture, and ash (\%) of the samples was performed in accordance with standard procedures delineated in American Society Standard Test Method (ASTM E870-82 (2013)). The fixed carbon (FC \%) was specified through subtracting VM \%, M \%, and ash $\%$ from $100 \%$. The ultimate analyses of $\mathrm{C}, \mathrm{H}, \mathrm{N}$, and $\mathrm{S}$ in the samples were done using an elemental analyzer (Vario MACRO cube, Elementar, Hanau, Germany), and $\mathrm{O}$ was calculated by the difference of $\mathrm{C}, \mathrm{H}, \mathrm{N}$, and $\mathrm{S}$ results from $100 \%$. The content of synthetic cellulose was determined according to GB/T 2677.10-1995, the content of a-cellulose was determined according to GB/T 744-1989, the content of lignin was determined according to GB/T 2677.8-1994, and the content of extract was determined by ethanol method.

\subsection{Scanning Electron Microscopy}

The sample was attached to a conductive adhesive on the sample table. The microstructures of the samples were observed through a S3400 scanning electron microscope (SEM, Thermo Fisher Scientific, Waltham, MA, USA) after being sprayed gold. The microconsolidation state of boric acid and distribution in the wood was analyzed by scanning the boron element using the energy dispersive X-ray (EDX) spectrometer combined with the SEM.

\subsection{FTIR and Raman Spectroscope}

The FTIR analysis of sample was determined at room temperature by using an FTIR instrument (Nicolet FTIR 6700, Thermo Fisher Scientific, Waltham, MA, USA). FTIR data were collected in the region between $4000 \mathrm{~cm}^{-1}$ and $600 \mathrm{~cm}^{-1}$ with 32 scans at a spectral resolution of $4 \mathrm{~cm}^{-1}$ via an ATR mode (Ge crystal) by using MCT detector with which liquid nitrogen was used as a refrigerant.

Raman spectra of liquid samples were recorded in the ranges of $100-3200 \mathrm{~cm}^{-1}$ on a Raman spectrometer (Renishaw inVia, Renishaw, London, UK) by using the following test conditions: laser: $532 \mathrm{~nm}$, exposure time: $10 \mathrm{~s}$, laser power (\%): 50; accumulative times: 10. The liquid samples were kept on glass slides. 


\subsection{Py-GC/MS Experiment}

Py-GC/MS experiment was performed on a Pyroprobe pyrolyzer (5200 series, CDS, USA) connected with GC/MS instrument (6890 GC/5973N MSD, Agilent, Palo alto, CA, USA). First, a $0.40 \mathrm{mg} \pm 2 \mathrm{mg}$ amount of sample was fed into the quartz tube with quartz wool on both sides and then placed into the pyroprobe. The pyroprobe was initially set for $40{ }^{\circ} \mathrm{C}$ and then ramped at $20^{\circ} \mathrm{C} / \mathrm{ms}$ to the final temperature of $500{ }^{\circ} \mathrm{C}$ for $60 \mathrm{~s}$. Then, the pyrolytic volatile products were transferred to the GC system and separated on the Agilent 122-4732 DB-17MS capillary column $(30.0 \mathrm{~m} \times 0.25 \mathrm{~mm} \times 0.25 \mu \mathrm{m}$ film thickness). The split ratio was 10:1 with helium carrier gas flow of $1 \mathrm{~mL} / \mathrm{min}$. The injector temperature was kept at $250{ }^{\circ} \mathrm{C}$, and the transfer line temperature was $285^{\circ} \mathrm{C}$ to avoid condensation or adsorption of semi-volatile products. The GC oven temperature was programmed at initial $40{ }^{\circ} \mathrm{C}$ for $4 \mathrm{~min}$, and then increased to $270{ }^{\circ} \mathrm{C}(5 \mathrm{~min})$ with a heating rate of $10^{\circ} \mathrm{C} / \mathrm{min}$, finally to $280^{\circ} \mathrm{C}(5 \mathrm{~min})$ with the heating rate of $10^{\circ} \mathrm{C} / \mathrm{min}$. MS was operated under the electron ionization of $70 \mathrm{eV}$ with a full scan mass / charge $(\mathrm{m} / \mathrm{z})$ range of 20-550. The temperatures of MS ion source and quadrupole were $230{ }^{\circ} \mathrm{C}$ and $150^{\circ} \mathrm{C}$, respectively. Py-GC/MS analysis for each sample was repeated twice and found with proper repeatability. The compounds obtained through GC/MS were identified via The National Institute of Standards and Technology (NIST) database by closet match in NIST MS Search 2.3 using identify type searching. The relative percentage content of a product was semi-quantified by comparing the peak area of the product with the total peak area of all detected products.

\subsection{TGA Experiment}

Thermogravimetric analysis, showing the loss in sample weight in response to increasing reaction temperature, was conducted at heating rates of $10^{\circ} \mathrm{C} / \mathrm{min}$ using TGA instrument (TG $209 \mathrm{~F} 1 \mathrm{Libra}, \mathrm{NETZSCH}$, Selb, Germany) from $30^{\circ} \mathrm{C}$ to $700{ }^{\circ} \mathrm{C}$. Small amounts of biomass samples about $5 \pm 0.2 \mathrm{mg}$ ) were used in alumina pans in each analysis. The scavenging air was $\mathrm{O}_{2}$, the protective air was $\mathrm{Ar}$, and the airflow was 50 and $30 \mathrm{~mL} / \mathrm{min}$, respectively.

\subsection{A Bench-Scale Fixed-Bed Pyrolysis Experiment}

The series of bench-scale pyrolysis experiments were carried out on a small fixedbed pyrolysis reactor. First, an amount of sample $(0.2 \mathrm{~g})$ was fed into the quartz tube with quartz wool on both sides. Then, the tube was rapidly placed into the pyroprobe (Pyrojector II, SGE, Ringwood, Australian) and kept for $5 \mathrm{~min}$ to full pyrolysis of the sample when the expected temperature $\left(500{ }^{\circ} \mathrm{C}\right)$ in the pyrolyzing furnace was ready. Almost simultaneously, the pyrolytic volatiles were swept out by purged gas (nitrogen), condensed, and further collected as the liquid products. The as-received liquid products were diluted in methanol for immediate GC-MS analysis (6890 GC/5973N MSD, Agilent, Palo alto, CA, USA). The sample was injected into the gas injection port with a manual GC syringe needle of $1 \mu \mathrm{L}$. The temperature of the injection port was $250{ }^{\circ} \mathrm{C}$. The sample was separated on a Agilent 122-4732 DB-17MS capillary column $(30.0 \mathrm{~m} \times 0.25 \mathrm{~mm} \times 0.25 \mu \mathrm{m})$ using helium $(1 \mathrm{~mL} / \mathrm{min})$ as the carrier gas with the split ratio of 30:1. The GC oven temperature was programmed at initial $40^{\circ} \mathrm{C}$ for $4 \mathrm{~min}$ and then increased to $270{ }^{\circ} \mathrm{C}(5 \mathrm{~min})$ with a heating rate of $10^{\circ} \mathrm{C} / \mathrm{min}$, finally to $280^{\circ} \mathrm{C}(5 \mathrm{~min})$ with the heating rate of $10^{\circ} \mathrm{C} / \mathrm{min}$. MS was operated under the electron ionization of $70 \mathrm{eV}$ with a full scan mass/charge $(\mathrm{m} / \mathrm{z})$ range of 20-550.

For material balance, all the input weight and coke weight were obtained by weighing on a balance with a precision of $0.1 \mathrm{mg}$. The desired input weight $\left(m_{\text {feed }}\right)$ was obtained by weighing the tube before and after sample loading. The weight of non-volatile solid residue $\left(m_{s}\right.$, including coke and tar) was acquired by weighing the pyrolysis tube (loaded with starting material) before and then again after reaction. The weight of the pyrolysis volatiles $\left(m_{v}\right.$, volatile substance includes the condensable liquid products and all non-condensable gas and vaporized chemicals) was acquired by deducting the non-volatile coke weight 
from the input weight (amount of starting material). Based on it, the yields of volatiles $\left(w_{\mathrm{v}} \%\right)$ and solid residue $\left(w_{\mathrm{s}} \%\right)$ are calculated by Equations (1) and (2), respectively.

$$
\begin{aligned}
& w_{\mathrm{s}} \%=m_{\mathrm{s}} / m_{\text {feed }} \times 100 \% \\
& w_{\mathrm{v}} \%=m_{\mathrm{v}} / m_{\text {feed }} \times 100 \%
\end{aligned}
$$

where $m_{s}$ refers to the weight of non-volatile solid residue, $m_{v}$ refers to the weight of pyrolysis volatiles, and $m_{\text {feed }}$ refers to the input weight of the starting materials.

\section{Conclusions}

Via impregnation treatment, boric acid successfully infiltrated into wood cell cavity and deposited on the cell wall evenly, helping boric acid function effectively in pyrolysis processes. FTIR analysis not only indicated that boric acid successfully deposited on wood flour, moreover it implied that some reactions occurred after BA treatment. TG-DTG analysis implied that there was a chemical interaction between boric acid and wood. Boric acid catalytically changed the pyrolysis path of wood, improving the thermal stabilities of wood remarkably; while wood may inhibit the BA dehydration from releasing water, it maintained some polyborate anions (incompletely dehydrated products of boric acid) in the residues. BA treatment simplified the product compositions of the wood flour samples. Specifically, it varied the decomposition paths of cellulose and hemicellulose to form acetic acid as the main product, while it inhibited the decomposing of lignin to form phenols. With the increasing of the BA/WF ratio, the content of acetic acid was increased gradually. Conversely, the contents of phenol and its derivatives were decreased after boric acid treatment. Converse variation trends for the contents of furfural and acetic acid at the high boric acid dosage implied that a competitive mechanism existed between them. Boric acid treatment significantly promoted the formation of acetic acid from biomass. It was mainly related to the catalytic effect of boric acid during the pyrolysis process and the partial hydrolysis of wood flour during the pretreatment process. The study provides a promising route for the preparation of acetic acid from woody biomass.

Supplementary Materials: The following are available online at https:/ / www.mdpi.com/2073-434 4/11/4/494/s1, Figure S1: X-ray diffraction pattern of boric acid (BA), cellulose, boric acid-treated cellulose $(B A / C e l l u l o s e=1.0)$, Figure S2: The original SEM figures of (a) wood flour $(\mathrm{WF})$ and BA $/ \mathrm{WF}$ mixtures with different mass ratios $((\mathrm{b}) \mathrm{BA} / \mathrm{WF}=0.1$; (c) $\mathrm{BA} / \mathrm{WF}=0.5$; (d) and (f) $\mathrm{BA} / \mathrm{WF}=1.0$; (e) $\mathrm{BA} / \mathrm{WF}=2.0$ ).

Author Contributions: Z.Z. conceived and designed the study and reviewed and edited the manuscript; X.H. performed the experiments and wrote the paper; Z.L. performed the experiments. All authors have read and agreed to the published version of the manuscript.

Funding: This work was supported by the National Natural Science Foundation of China (Grant No. 31890773 and 31670570) and the Fundamental Research Funds for the Central Universities under the Project Number 2572020BB03.

Data Availability Statement: All data generated or used during the study appear in the submitted article and its Supplementary Materials.

Acknowledgments: This material is based upon work performed at the MOE Key Laboratory of Bio-based Material Science and Technology at Northeast Forestry University.

Conflicts of Interest: The authors declare no conflict of interest.

\section{References}

1. Dai, L.; Wang, Y.; Liu, Y.; He, C.; Ruan, R.; Yu, Z.; Jiang, L.; Zeng, Z.; Wu, Q. A review on selective production of value-added chemicals via catalytic pyrolysis of lignocellulosic biomass. Sci. Total Environ. 2020, 749, 142386. [CrossRef] [PubMed]

2. Dhyani, V.; Bhaskar, T. A comprehensive review on the pyrolysis of lignocellulosic biomass. Renew. Energy 2018, $129,695-716$. [CrossRef] 
3. González, M.G.; Ohra, T.; Perez, D.D.S.; Tamminen, T.; Dupont, C. Influence of step duration in fractionated Py-GC/MS of lignocellulosic biomass. J. Anal. Appl. Pyrol. 2019, 137, 195-202. [CrossRef]

4. Wang, S.; Dai, G.; Yang, H.; Luo, Z. Lignocellulosic biomass pyrolysis mechanism: A state-of-the-art review. Prog. Energy Combust. Sci. 2017, 62, 33-86. [CrossRef]

5. Liu, Q.; Chai, Y.; Ni, L.; Lyu, W. Flame Retardant Properties and Thermal Decomposition Kinetics of Wood Treated with Boric Acid Modified Silica Sol. Materials 2020, 13, 4478. [CrossRef] [PubMed]

6. Semaan, J.N.; Huron, M.; Daouk, E.J. Pilot scale pyro-gasification of biomass and waste: Char characterization. Biomass Convers. Bior. 2021, 8, 1-15.

7. Mokrzycki, J.; Gazińska, M.; Fedyna, M.; Karcz, R.; Lorenc, E.; Rutkowski, P. Pyrolysis and torrefaction of waste wood chips and cone-like flowers derived from black alder (Alnus glutinosa L. Gaertn.) for sustainable solid fuel production. Biomass Bioenerg. 2020, 143, 105842. [CrossRef]

8. Jeon, M.J.; Choi, S.J.; Yoo, K.S.; Ryu, C.; Park, S.H.; Lee, J.M.; Jeon, J.K.; Park, Y.K.; Kim, S. Copyrolysis of block polypropylene with waste wood chip. Korean J. Chem. Eng. 2011, 28, 497-501. [CrossRef]

9. Laurens, L.M.L.; Nagle, N.; Davis, R.; Sweeney, N.; Wychen, S.; Lowell, A.; Pienkos, P.T. Acid-catalyzed algal biomass pretreatment for integrated lipid and carbohydrate-based biofuels production. Green Chem. 2015, 17, 1145-1158. [CrossRef]

10. Chen, S.; Wojcieszak, R.; Dumeignil, F.; Marceau, E.; Royer, S. How Catalysts and Experimental Conditions Determine the Selective Hydroconversion of Furfural and 5-Hydroxymethylfurfural. Chem. Rev. 2018, 118, 11023-11117. [CrossRef]

11. Chen, X.; Yang, H.; Chen, Y.; Chen, W.; Lei, T.; Zhang, W.; Chen, H. Catalytic fast pyrolysis of biomass to produce furfural using heterogeneous catalysts. J. Anal. Appl. Pyrol. 2017, 127, 292-298. [CrossRef]

12. Iliopoulou, E.F.; Stefanidis, S.; Kalogiannis, K.; Psarras, A.C.; Delimitis, A.; Triantafyllidis, K.S.; Lappas, A.A. Pilot-scale validation of Co-ZSM-5 catalyst performance in the catalytic upgrading of biomass pyrolysis vapours. Green Chem. 2014, 16, 662-674. [CrossRef]

13. Dickerson, T.; Soria, J. Catalytic Fast Pyrolysis: A Review. Energies 2013, 6, 514-538. [CrossRef]

14. Ma, L.; Wang, T.; Liu, Q.; Zhang, X.; Ma, W.; Zhang, Q. A review of thermal-chemical conversion of lignocellulosic biomass in China. Biotechnol. Adv. 2012, 30, 859-873. [CrossRef] [PubMed]

15. Wang, K.; Kim, K.H.; Brown, R.C. Catalytic pyrolysis of individual components of lignocellulosic biomass. Green Chem. 2014, 16, 727-735. [CrossRef]

16. Zhou, X.; Li, W.; Mabon, R.; Broadbelt, L.J. A Critical Review on Hemicellulose Pyrolysis. Energy Technol. 2017, 5, 52-79. [CrossRef]

17. Branca, C.; Di Blasi, C.; Galgano, A. Catalyst Screening for the Production of Furfural from Corncob Pyrolysis. Energy Fuels 2012, 26, 1520-1530. [CrossRef]

18. Hu, B.; Lu, Q.; Wu, Y.T.; Zhang, Z.X.; Cui, M.S.; Liu, D.J.; Dong, C.Q.; Yang, Y.P. Catalytic mechanism of sulfuric acid in cellulose pyrolysis: A combined experimental and computational investigation. J. Anal. Appl. Pyrol. 2018, 134, 183-194. [CrossRef]

19. Liu, Q.; Wang, J.; Zhou, J.; Yu, Z.; Wang, K. Promotion of monocyclic aromatics by catalytic fast pyrolysis of biomass with modified HZSM-5. J. Anal. Appl. Pyrol. 2021, 153, 104964. [CrossRef]

20. Hu, B.; Lu, Q.; Wu, Y.T.; Xie, W.L.; Cui, M.S.; Liu, J.; Dong, C.Q.; Yang, Y.P. Insight into the formation mechanism of levoglucosenone in phosphoric acid-catalyzed fast pyrolysis of cellulose. J. Energy Chem. 2020, 43, 78-89. [CrossRef]

21. Kumar, R.; Strezov, V. Thermochemical production of bio-oil: A review of downstream processing technologies for bio-oil upgrading, production of hydrogen and high value-added products. Renew. Sustain. Energy Rev. 2021, 135, 110152. [CrossRef]

22. Mohan, D.; Pittman, C.U.; Steele, P.H. Pyrolysis of Wood/Biomass for Bio-Oil: A Critical Review. Fuels 2006, 20, 848-889. [CrossRef]

23. Lin, L.; Sheveleva, A.M.; Silva, I.; Parlett, C.M.A.; Tang, Z.; Liu, Y.; Fan, M.; Han, X.; Carter, J.H.; Tuna, F.; et al. Quantitative production of butenes from biomass-derived gamma-valerolactone catalysed by hetero-atomic MFI zeolite. Nat. Mater. 2020, 19, 86-93. [CrossRef]

24. Sudarsanam, P.; Peeters, E.; Makshina, E.V.; Parvulescu, V.I.; Sels, B.F. Advances in porous and nanoscale catalysts for viable biomass conversion. Chem. Soc. Rev. 2019, 48, 2366-2421. [CrossRef] [PubMed]

25. Rahman, M.M.; Chai, M.; Sarker, M.; Nishu; Liu, R. Catalytic pyrolysis of pinewood over ZSM-5 and CaO for aromatic hydrocarbon: Analytical Py-GC/MS study. J. Energy Inst. 2020, 93, 425-435. [CrossRef]

26. Wang, Y.; Huang, Q.; Zhou, Z.; Yang, J.; Qi, F.; Pan, Y. Online Study on the Pyrolysis of Polypropylene over the HZSM-5 Zeolite with Photoionization Time-of-Flight Mass Spectrometry. Energy Fuels 2015, 29, 1090-1098. [CrossRef]

27. Rutkowski, P. Pyrolysis of cellulose, xylan and lignin with the $\mathrm{K}_{2} \mathrm{CO}_{3}$ and $\mathrm{ZnCl}_{2}$ addition for bio-oil production. Fuel Process. Technol. 2011, 92, 517-522. [CrossRef]

28. Yamauchi, S.; Sakai, Y.; Watanabe, Y.; Kubo, M.K.; Matsue, H. Distribution of boron in wood treated with aqueous and methanolic boric acid solutions. J. Wood Sci. 2007, 53, 324-331. [CrossRef]

29. Shelke, K.F.; Sapkal, S.B.; Kakade, G.K.; Shinde, P.V.; Shingate, B.B.; Shingare, M.S. Boric acid as an efficient catalyst for the synthesis of 1,1-diacetate under solvent-free condition. Chin. Chem. Lett. 2009, 20, 1453-1456. [CrossRef]

30. Luo, B.; Li, R.; Shu, R.; Wang, C.; Chen, Y.J. Boric Acid as a Novel Homogeneous Catalyst Coupled with Ru/C for Hydrodeoxygenation of Phenolic Compounds and Raw Lignin Oil. Ind. Eng. Chem. Res. 2020, 59, 17192-17199. [CrossRef]

31. Pathan, S.; Mahaparale, P.; Deshmukh, S.; Une, H.; Arote, R.; Sangshetti, J. Boric Acid: A Versatile Catalyst in Organic Synthesis. Applications of Nanotechnology for Green Synthesis, 3rd ed.; Springer: Cham, Switzerland, 2020; pp. 457-483. 
32. Makkee, M.; Kieboom, A.; Bekkum, H.V. Studies on borate esters III. Borate esters of D-mannitol, D-glucitol, D-fructose and D-glucose in water. Recueil Travaux Chimiques Pays-Bas 2015, 104, 89-95. [CrossRef]

33. Wang, Q.; Li, J.; Winandy, J. Chemical mechanism of fire retardance of boric acid on wood. Wood Sci. Technol. 2004, 38, 375-389. [CrossRef]

34. Zhang, J.; Koubaa, A.; Xing, D.; Wang, H.; Wang, Y.; Liu, W.; Zhang, Z.; Wang, X.; Wang, Q. Conversion of lignocellulose into biochar and furfural through boron complexation and esterification reactions. Bioresour. Technol. 2020, 312, 123586. [CrossRef]

35. Hansen, T.S.; Mielby, J.; Riisager, A.J. Synergy of boric acid and added salts in the catalytic dehydration of hexoses to 5hydroxymethylfurfural in water. Green Chem. 2011, 13, 109-114. [CrossRef]

36. Yu, L.L.; Cai, J.; Li, H.; Lu, F.; Qin, D.C.; Fei, B.H. Effects of Boric Acid and/or Borax Treatments on the Fire Resistance of Bamboo Filament. BioResources 2017, 12, 5296-5307. [CrossRef]

37. Donmez Cavdar, A.; Mengeloğlu, F.; Karakus, K. Effect of boric acid and borax on mechanical, fire and thermal properties of wood flour filled high density polyethylene composites. Measurement 2015, 60, 6-12. [CrossRef]

38. Di Blasi, C.; Branca, C.; Galgano, A. Flame retarding of wood by impregnation with boric acid-Pyrolysis products and char oxidation rates. Polym. Degradand Stabil. 2007, 92, 752-764. [CrossRef]

39. Salman, S.; Pétrissans, A.; Thévenon, M.F.; Dumarçay, S.; Perrin, D.; Pollier, B.; Gérardin, P. Development of new wood treatments combining boron impregnation and thermo modification: Effect of additives on boron leachability. Eur. J. Wood Wood Prod. 2014, 72, 355-365. [CrossRef]

40. Kang, W.; Zhang, Z. Selective Production of Acetic Acid via Catalytic Fast Pyrolysis of Hexoses over Potassium Salts. Catalysts 2020, 10, 502. [CrossRef]

41. Guo, T.; Li, X.; Liu, X.; Guo, Y.; Wang, Y. Catalytic Transformation of Lignocellulosic Biomass into Arenes, 5-Hydroxymethylfurfural, and Furfural. ChemSusChem 2018, 11, 2758-2765. [CrossRef] [PubMed]

42. Li, J.; Xia, S.P.; Gao, S.Y. FT-IR and Raman spectroscopic study of hydrated borates. Spectrochim. Acta A 1995, 51, 519-532.

43. Zhu, L.; Tao, Y.; Jiang, W.; Gao, S.J. FT-IR and Raman spectroscopic study of hydrated rubidium (cesium) borates and alkali double borates. Russ. J. Inogr. Chem. 2007, 52, 1786-1792.

44. Derail, H. Thermal decomposition kinetics of sodium perborate tetrahydrate to sodium metaborate by using model-fitting and model-free methods. Korean J. Chem. Eng. 2011, 28, 2002-2008.

45. Balci, S.; Sezgi, N.A.; Esin, E. Boron Oxide Production Kinetics Using Boric Acid as Raw Material. Ind. Eng. Chem. Res. 2012, 51, 11091-11096. [CrossRef]

46. Usino, D.O.; Supriyanto, A.; Ylitervo, P.; Pettersson, A.; Richards, T. Influence of temperature and time on initial pyrolysis of cellulose and xylan. J. Anal. Appl. Pyrol. 2020, 147, 104782. [CrossRef]

47. Wang, S.; Ru, B.; Lin, H.; Luo, Z. Degradation mechanism of monosaccharides and xylan under pyrolytic conditions with theoretic modeling on the energy profiles. Bioresour. Technol. 2013, 143, 378-383. [CrossRef] [PubMed]

48. Zhang, Z.; Zhang, C.; Zhang, L.; Li, C.; Zhang, S.; Liu, Q.; Wang, Y.; Gholizadeh, M.; Hu, X. Pyrolysis of cellulose with co-feeding of formic or acetic acid. Cellulose 2020, 27, 4909-4929. [CrossRef]

49. Zhao, C.; Jiang, E.; Chen, A. Volatile production from pyrolysis of cellulose, hemicellulose and lignin. J. Energy Inst. 2017, 90, 902-913. [CrossRef]

50. Collard, F.X.; Blin, J. A review on pyrolysis of biomass constituents: Mechanisms and composition of the products obtained from the conversion of cellulose, hemicelluloses and lignin. Renew. Sustain. Energ. Rev. 2014, 38, 594-608. [CrossRef]

51. Wang, S.; Ru, B.; Lin, H.; Sun, W. Pyrolysis behaviors of four O-acetyl-preserved hemicelluloses isolated from hardwoods and softwoods. Fuel 2015, 150, 243-251. [CrossRef]

52. Hu, B.; Lu, Q.; Zhang, Z.X.; Wu, Y.T.; Li, K.; Dong, C.Q.; Yang, Y.P. Mechanism insight into the fast pyrolysis of xylose, xylobiose and xylan by combined theoretical and experimental approaches. Combust. Flame 2019, 206, 177-188. [CrossRef]

53. Yemis, O.; Mazza, G. Acid-catalyzed conversion of xylose, xylan and straw into furfural by microwave-assisted reaction. Bioresour. Technol. 2011, 102, 7371-7378. [CrossRef] [PubMed]

54. Luo, Y.; Li, Z.; Zuo, Y.; Su, Z.; Hu, C. A Simple Two-Step Method for the Selective Conversion of Hemicellulose in Pubescens to Furfural. ACS Sustain. Chem. Eng. 2017, 5, 8137-8147. [CrossRef] 